\title{
Gender Disparity And Women Leadership In Educational Institutions
}

\author{
Tayyaba Zarif \\ Department of Education \\ Shaheed Benazir Bhutto University \\ Safia Urooj \\ Department of Teacher Education \\ University of Karachi \\ Abdul Nabi Gorchani \\ Department of Education \\ Shaheed Benazir Bhutto University
}

\begin{abstract}
Since the world has rapidly turned into the global village in very short span of time by entering into the $21^{\text {st }}$ Century. The advanced communication has made everything available at the door steps. Huge developments in every sphere of life have been taken place despite human beings have still been accomplishing much-more out of which the inequity and gender disparity is one of those concerns being faced by the world. Now days mostly Pakistani women are active to take part in every field like health, politics even in labor and especially in education sector from lower to higher education. Pakistani women are also playing the important role in the field of education specifically in educational administrative positions from lower to higher education. This research study intended to measure the magnitude of gender disparity in educational institutions of District Shaheed Benazirabad (SBA) of Province Sindh, Pakistan. This research study was quantitative by method and descriptive in nature. The population of this research study was, those women leaders working in educational institutions of District Shaheed Benazirabad, and were performing leadership role in one or other way. The sample of this study was 48 women leaders having proportion of seventy percent of the total population. The data was analyzed through SPSS software, 22 version. This research study found that women leaders working in higher educational institutions have least career related opportunities, they are also put on distance to possess managerial and administrative opportunities and have least support from their high ups and stakeholders as compare to their counter gender in higher educational institutions of District Shaheed Benazirabad. This research study recommended that the women leaders might be given career, managerial and administrative related opportuinities and support and encouragement from their high ups and stakeholders for carrying out their leadership responsibilities.
\end{abstract}

Keywords: Gender Disparity, Women Leadership, Educational Institutions, Modern Development, Administrative Opportunities. 


$$
\begin{aligned}
& \text { تلخيص }
\end{aligned}
$$

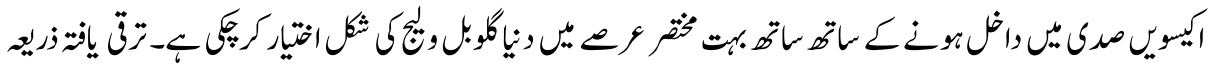

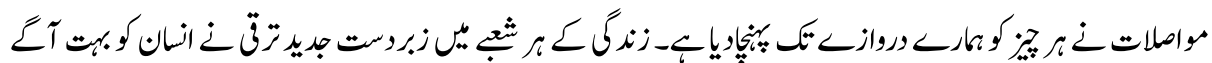

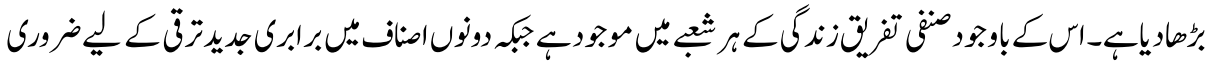

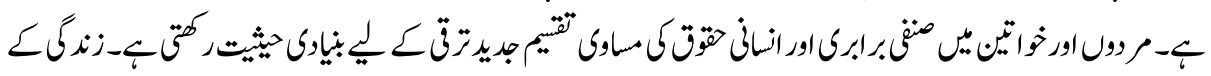

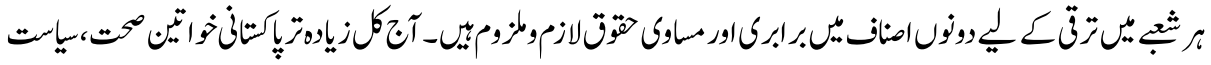

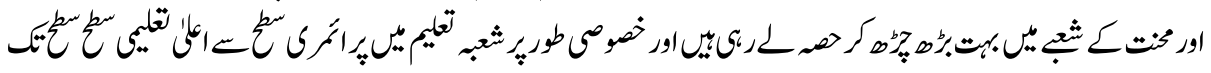

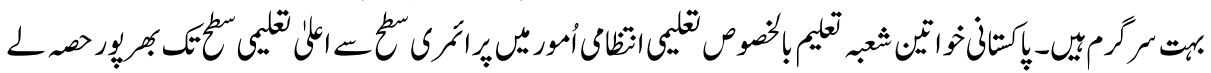

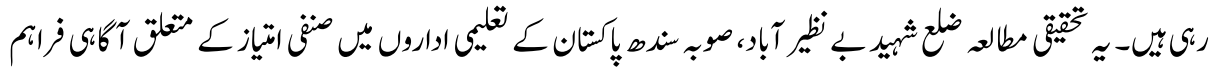

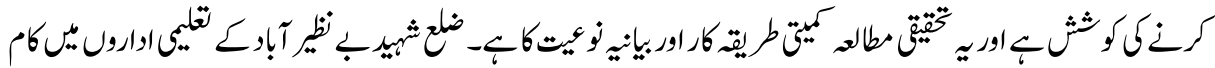

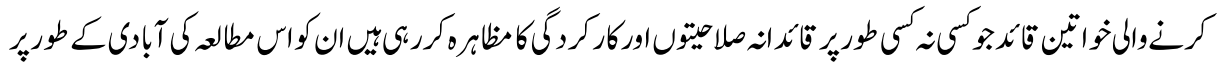

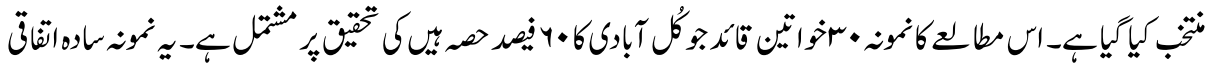

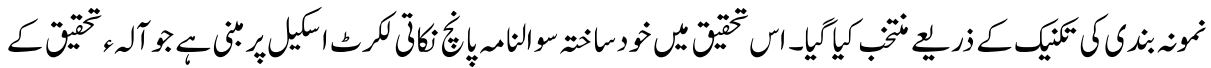

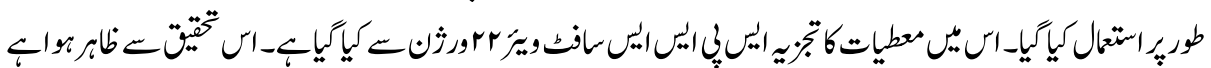

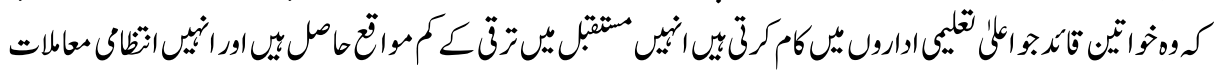

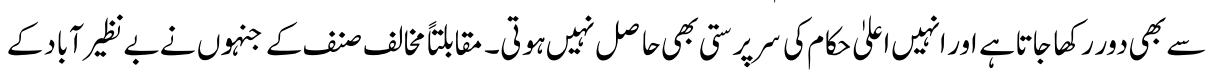

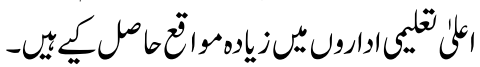

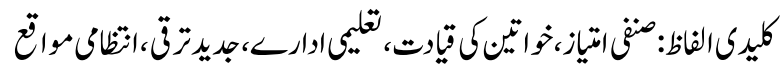

\section{Introduction}

Sen \& Mukherjee (2014) highlighted that the Millennium Development Goal three and four were two of the eight internationally agreed MDGs regarding gender equality and empowerment, and elimination of gender disparity in educational system, to achieve those MDGs the dead line was set up to the end of the 2015.The entire world tried to meet the millennium development goals' dead line set by UNESCO, by reconsidering their policies and educational planning and Pakistan did so as well, but unfortunately the goalswere not fully achieved and still endeavors were being made to achieve them (DIRGHA, 2006). Pakistan is still far away from achieving that particular task, but endeavors are being made to come to close the target but seems yet to be accomplished. Achieving gender parity in leadership is, first and perhaps most important matter of fairness (Blackmore, 2006; Poliner \& Stefkovic, 2016). 
According to Cheng (2004), leaders are powerful, so when women are excluded from top leadership, they are denied power to make a difference in the world. Leaders enjoy high status and privilege, and leadership in one area opens doors to other opportunities, which further amplifies the perks of and for leadership, (Cheng, 2004). In most of the organizations, the top leader is also the most highly compensated individual, because the managers and supervisors tend to have higher salaries than workers who are not in leadership roles. The gender inequality and gender disparity are most immediate discussions in the circles of the researchers, (Smulders, 1998; UNESCO, 2002). The world, globally is a man dominated society, it spares least opportunities for their opponent gender, which leads towards gender disparity, (Blair, 2002; Doob, 2015). The gender disparity is found all over the world at different extents. Number of the countries though have encountered the issue but yet they have to accomplish the target. The gender disparity prevails in Pakistani educational institutions as well, (Khalid, 2011). Pakistan and Samoa, countries where women are very under-represented in positions of power, have made marginal gains by installing minimal quotas. In Punjab province, Pakistan, the quota of women increased from 5\% to 15\% in 2016/7, (Agha, 2016).In 2013, the Samoan parliament passed an act that required $10 \%$ of parliamentarians to be women. However, given that parliamentarians must hold a title of leadership (Matai) in their village, and that only $11 \%$ of people with this title were women, more needs to be done to expand access for women. Batool \& Sajid, (2013), who conducted a research study on women's' representation in higher educational management in Pakistan, found that some of the structural factors such as mentoring, networking, selection and promotion practices and gender equity and inequality were the barriers to the career advancement of the women. In spite, women in education leadership positions provide role models that can help encourage female student retention, (Kagoda, 2011). According to Hird, (2004), the natural biological differences in human beings decide the masculine and the feminine identity. The harmonic changes and the body structure and physical appearances differ in masculine and feminine physic. The feminine is supposed as a weaker than the masculine structure. These biological differences have become the basis of proposition that feminine cannot perform as effective as masculine can perform. From the very beginning masculine used to perform and fulfill those responsibilities which needed much power and severness of physic. The case with women in this regards was adverse, (Hird, 2004). Biologically women tended a soft structure which made man to make decisions. This authority of the man is bestowed by Almighty Allah, we call biological differences is being misused by man. It is why, the socio-cultural roles and the responsibilities are made by man or socially and culturally are man dominated in the world. In the man dominated society it is decided by the masculine to what to do either by him or by opposite sex, whereas no feminine is given the right to its needed extent to make decisions for masculine sex, is known as gender disparity (Clerkin, 2017). The male dominancy snatched out the rights of the feminine in number of ways. Inequality can be defined as "lack of evenness or social disparity". It can also be defined as treating individuals 
unequally on the basis of their gender. It occurs from different socially assigned gender roles, (Huma, 2016). In mid-1960's gender disparity appeared to narrow. In 1965, 5\% of students in professional programs were female. In 1985 this number increased to $40 \%$ in law and medicine, above $30 \%$ in dentistry and business school. There are few women in boards of directors and in senior positions in the private sectors. Despite female leaders influences the extent of emphasis placed on gender equality in policy and practice, (Catherine \& Grossman, 2008). Women in leadership positions tend of favor the equitable redistribution of resources, and legislatures with a higher share of women on an average tend to support health, education and social welfare spending at the expense of defense spending. Across 103 countries, countries that mandated a percentage of women in their legislatures spent 3.4 percentage points more on social welfare than those that did not, (Morley \& Crossouard, 2015). But the continuing dominance of men in decisionmaking posts limits women's voice in and ability to influence policy design at international, central and local government levels, as well as at level of schools and communities.

The situation in the educational institutions in District Shaheed Benazirabad of province Sindh of Pakistan has no exception. Especially in the higher educational institutions the women being in smaller proportion have been deprived of their opportunities. In this research study an attempt is made to measure the extent of gender disparity in educational institution of District Shaheed Benazirabad. The prime focus of this research study was to measure the extent of gender disparity in timely discussion of abroad and local scholarship opportunities encouragement to women leaders to avail those opportunities with equal proportion, their equal participation in continuous professional development trainings/ programs, to have say about their career opportunity concerns, equal nomination for managerial and administrative responsibilities, having equal opportunities of becoming heads of institutional committees, encouragement and support to them from their high-ups\& stakeholders and a feeling of confidence to discuss matters with masculine high-ups\& stakeholders in their institutions.

\section{Research Objectives}

1. To study the gender disparity in Career related opportunities to the women leaders as compare to their counter gender in educational Institutions.

2. To study the gender disparity in managerial and administrative opportunities available to the women leaders as compare to their counter gender in educational institutions

3. To study the support given by high ups\& stakeholders to the women leaders as compare to their counter gender in educational institutions. 


\section{Research Questions}

1. What kind of gender disparity incareer related opportunities are faced by the women leaders as compare to their counter gender in educational Institutions?

2. To what extent the managerial and administrative opportunities are available to the women leaders as compare to their counter gender in educational institutions.

3. To what extent thehigh ups \& stakeholders are supportive to the working women as a leadersas compare to their counter gender in educational Institutions.

\section{Literature Review}

According to Huma, (2016) gender refers to social roles to women and men. According to her, gender also refers to the behavior attitude and characteristics for man and women. According to the Williams, (2004), which referred world health organization (WHO), sex refers to the biological and physiological characteristics which define masculine and feminine whereas gender is referred to socially assembled and erected responsibilities and roles, behaviors, activities and attributes that a particular society set fit for men and women, (Devineau, Couvry, Feliu, \& Renard, 2018). Gender inequality or disparity is referred to masculine and feminine are not equal, (Cubillo, 2003; Asya, 2007; Rostron, 2009). Gender affects ones' actual involvement. Such differences arise from variation in biology, psychology and cultural norms, ((Funk, 2004; Devineau, Couvry, Feliu, \& Renard, 2018). The biological study suggested that the natural differences exist between the sexes based on such factors, mostly on their reproductive roles. It further suggested that related to physical strengths the sexes also differ, whereas the extent of differences are unpredictable, (Devineau, Couvry, Feliu, \& Renard, 2018). The study of human psychology suggests that, from their birth, the feminine and the masculine are exposed differently and have different environments during the journey of their entire life, the both male and female are treated differently and have different path until they become able to make choices by their own which deciders, sociologically are differentiated for their social responsibilities known as gender, (Devineau, Couvry, Feliu, \& Renard, 2018). The research studies depict that the world is a man dominated (Madhani, 2007) to make decisions for both genders. Even in the closer relationships, the gender equality is under discussion, wherein the authority lies in the hands of the male, (Devineau, Couvry, Feliu, \& Renard, 2018). According to Sen \& Mukherjee, (2014), the millennium Development Goal three which was about the gender equality and empowerment and the fourth is about the elimination of gender disparity in educational system, the dead line set for achieving those millennium goals was up to 2015. The entire world tried to meet the dead line by reconsidering their policies and educational planning and Pakistan did so as well but unfortunately the goal is no accomplished. Pakistan is still far away from achieving that particular task, but endeavors are being made to come to close the target but seems yet to be accomplished. All along with other challenges women face personal challenges to 
encounter at first before intending to possess leadership positions for better performance. The one of the double burden syndrome responsibility which makes Asian and African women bound to perform dual responsibility at office and at home to manage office and house hold affairs and activities, (Lerner \& Keltner, 2001). According to the research study conducted by Madhani, (2007), who narrated that the leaders identity was dependent upon the logic of purposes, which results how much a leader is effective when carrying out goals. It further narrated that because of the sense of purpose leaders will to challenge the status quo, this requires a leader should be decision maker, assertive and independent, where as an assumption suggests that the women are supposed to be friendly, caring and selfless so that they do not handle the leadership roles effectively, which also leads towards the gender disparity. The gender biasness creates obstructions for women and causes man to prefer those that are similar to them, which result of masculine dominancy over feminine to keep women away from leadership roles. According to Devineau S. C., (2018), globally women leaders face challenges at their work place either holding key positions or otherwise. According to their research study the women did not possess enough space on leadership responsibilities in educational or other institutions or organizations. They identified that the women do not equal opportunity of availing education or are employed as compare to the counterparts. The same prevails in educational institutions as well. The institutions being man dominated, women lake support from their male counter parts which shakes their confidence level. Which ultimately results sharing and discussing issues with counterparts or even with high ups for solutions. According to a research study conducted by Catherine \& Grossman, (2008), found out that women leaders do face gender biasness for their promotions on leadership positions, when their performance is being evaluated for such positions. A proposition according to the DDI reveals that it was assumed that women did not perform as better as their counter gender, which ultimately limits the leadership opportunities for women leaders at every level and in every organization or institution. A study conducted by Çobanoğlu, (2018) in Turkish higher education determining proportion of female academicians found that the women had decreased as the demands of the degrees increased, they further found that the women leaders were not given equal opportunity in decision making framework even though they had fulfilled required conditions. Their study further found that as the academia increases, the rate of the women at leadership positions decreases (Çobanoğlu, 2018). The operational stages for promotional process identified by Çobanoğlu, (2018) show five very crucial stages such as undergraduate studies graduate studies, post-doctoral fellowship, assistant professorship and tenured professorship, their study identified that the women section quits their journey somewhere in that operational process, this may be because of fear of least support to them. Their study further found that the women leaders have little visibility on high leadership positions at organizational level. All along with other barriers, the barrier for women was their role in their society, it is described as, and that how much time the women section can spare from their own family life, their role and 
responsibilities related to their social life erects barriers to possess a leadership responsibility in an organization (Çobanoğlu, 2018). Their study found that the women were shown in inequality, whether the rate of the women leaders was increasing or not, in educational institutions in Turkey (Çobanoğlu, 2018). A research work conducted by Karadağ, (2018) and earlier identified by UNESCO, (2002), wherein the researchers have found that the leadership role has reflections on their family life, ultimately making them to keep themselves away from leadership role, the study further found that the female leaders had have to handle and fulfill dual responsibility, in their workplace and at home and supported to the previous study conducted by, (Chege, 2006). They further found that the work place practices and culture, the behavior of colleagues, other leaders and social biases which makes them hesitant to work and perform their leadership role effectively (Karadağ, 2018). They further found that the bureaucratic behavior of upper level leadership, lack of support in official financial matters, and least mentor ship was also a kind of gender disparity (Karadağ, 2018). According to the research study of Sales, (1999) Karadağ, (2018) the female leaders in educational institutions found facing some perceptional and attitudinal disparity behavior such as the female leaders described that they had have defensive exposure, selflessness, no wish to deny man imposed authority to shake their self-confidence and work appreciation. According to the Bush, (2007) and Devineau, (2018) ones's work autonomy in academic and leadership endeavors when challenged, has become inconsistent leadership role, such resistance from immidiate surrounding has been the norm of the academic universe. A study conducted by Bolden, (2004) in his research report and Shaukat, (2014), on Gender Discrimination in Education in Pakistan, concluded that the gender discrimination was found in capacity building trainings and ICT trainings, availability and use of resources at high range. They further concluded that the gender disparity was found in the areas such as, in decision making, policy formulation, professional development, academic affairs, particularly in the curriculum evaluation, making availability and utilization of resources, (Shaukat, 2014). A research study conducted by Rarieya, (2017) identified that the women had to continuously prove themselves capable at their work places as compare to their counter gender. The gender biasness remains in search to find out the weaknesses for criticism and shaking of confidence of women leaders according to the research study which was conducted on leadership in Pakistan and Kenyan educational institutions identified that men do not spare themselves to create difficulties for women working as a leader, their research identified that women are harassed and shouted at by counter gender, and even the parents of the students take women leaders very light and show dominancy simply thinking that the opposite gender is weaker than them. Their study also found that the opposite gender when comes into contact with them felt uncomfortable seeing a women on leadership position, their male subordinates felt difficulty to obey their instructions, (Rarieya, 2017). The recommendations of the research study conducted by Stephen ,et al., (2012), suggested that educational disparity included which overlap with social class, biased and indifferent treatment in educational system and reciprocal differences in 
educational system. A study conducted by Karadağ, (2018) showed gender inequality in their self-representation. Clerkin, (2017) in their research study revealed that diversity in an organization made institutions a better work place, it also helped employees' retention in an organization. Batool \& Sajid, (2013), who conducted a research study on women's' representation in higher educational management in Pakistan, found that some of the structural factors such as mentoring, networking, selection and promotion practices and gender equity and inequality were the barriers to the career advancement of the women. According to the Sen \& Mukherjee, (2014), the women encounter household and organizational barriers which are in larger magnitude in private sector educational institutions. According to Ministry of Planning and Development, (2015) equity by 2015, Pakistan aimed to achieve Millennium Development Goals as well as eradicate gender disparity at all levels. Ministry of Pakistan had submitted education for all review report 2015, in the perspective of World Education Forum 2015. That report was submitted in response to invitation from UNESCO to their member States to calculate progress made since year 2000 (Ministry of Planning and Development, 2015). The report was published in 2015, depicted that the Pakistan education sector was facing different challenges and among them were the gender access and equity at all levels, (Baluch, 2009; Huma, 2016).

\section{Research Methodology}

The most of the research studies were found conducting such type of research studies by applying qualitative research methodology (Khalid, 2011) and (Suleman, 2015). Whereas all along with qualitative researches, the researchers have also conducted such type of researches by applying quantitative research methodology (Efeoğlu, 2017; Karadağ, 2018). In this research study the researchers have applied quantitative research method. The population of this research study was those women leaders, who were working in educational institutions of District Shaheed Benazirabad, and were carrying out leadership roles in one or other way. The sample of this study was 48 women leaders having proportion of seventy percent of the population. The sample was selected through simple random sampling technique. The tool was a self-designed questionnaire on five point Likert scale, containing fifteen statements. The validity and reliability of the tool was ensured after discussion with three women leaders working at three different educational institutions. Furthermore the tool was piloted on five percent of the sample and was found valid and reliable. After ensuring the validity and reliability of the tool, it was administered on sample for data collection. The collected data was analyzed through SPSS software, 22 version. The results were drawn in mean scores and standard deviation. The number of researchers in one or the other way agreed on mean scores, (Sullivan, Anthony , \& Artino, 2013; Kostoulas, 2013; Mahmutovic , 2015). On the other hand number of researches had relied upon mean score such as Organization of Economic and Cultural Development (OECD) in 2009 had conducted a research in twenty three countries under TALIS had also relied upon mean scores (OECD, 2009). Mehmood, (2011) who wrote his $\mathrm{Ph}$. D thesis relied upon mean score of the Likert scale while 
conducting research study on impact of administrative styles of secondary school Head Masters on teachers performance in the than NWFP and now KPK. It is why the mean statistics had relied upon in this research study as well.

\section{Data Analysis}

Table: 6.1

Tabulatory presentation of mean scores for each statement

\begin{tabular}{|l|c|c|}
\hline \multicolumn{1}{|c|}{ Statements } & Mean & $\begin{array}{c}\text { Std. } \\
\text { Deviation }\end{array}$ \\
\hline $\begin{array}{l}\text { Timely discussion about abroad and local scholarship } \\
\text { opportunities }\end{array}$ & 2.92 & .846 \\
\hline $\begin{array}{l}\text { Encouragement to avail abroad and local scholarship } \\
\text { opportunities }\end{array}$ & 3.06 & .836 \\
\hline Equal opportunities to avail scholarship opportunities & 2.79 & .849 \\
\hline Participating in continuous professional development programs & 2.71 & .771 \\
\hline To have say about their career opportunity concerns & 3.04 & .743 \\
\hline $\begin{array}{l}\text { Equal nomination for managerial and administrative } \\
\text { responsibilities. }\end{array}$ & 2.92 & .846 \\
\hline Abidance by the instructions by their subordinates & 2.79 & .798 \\
\hline No difficulty to instruct to their subordinates & 2.75 & .729 \\
\hline Working fearlessly & 2.96 & .771 \\
\hline Opportunities for becoming heads of the institutional committees & 2.75 & .812 \\
\hline Encouragement for leadership positions & 2.73 & .707 \\
\hline $\begin{array}{l}\text { Equality by the stake holders for managerial and administrative } \\
\text { responsibilities }\end{array}$ & 2.85 & .899 \\
\hline $\begin{array}{l}\text { Support by the stake holders for managerial and administrative } \\
\text { responsibilities }\end{array}$ & 3.02 & .838 \\
\hline Fear of un-even behavior from the stakeholders & 2.81 & .867 \\
\hline Hesitation in contacting with stakeholders for leadership queries. & 3.06 & .810 \\
\hline
\end{tabular}




\section{Graph 6.1 Item Wise Results}

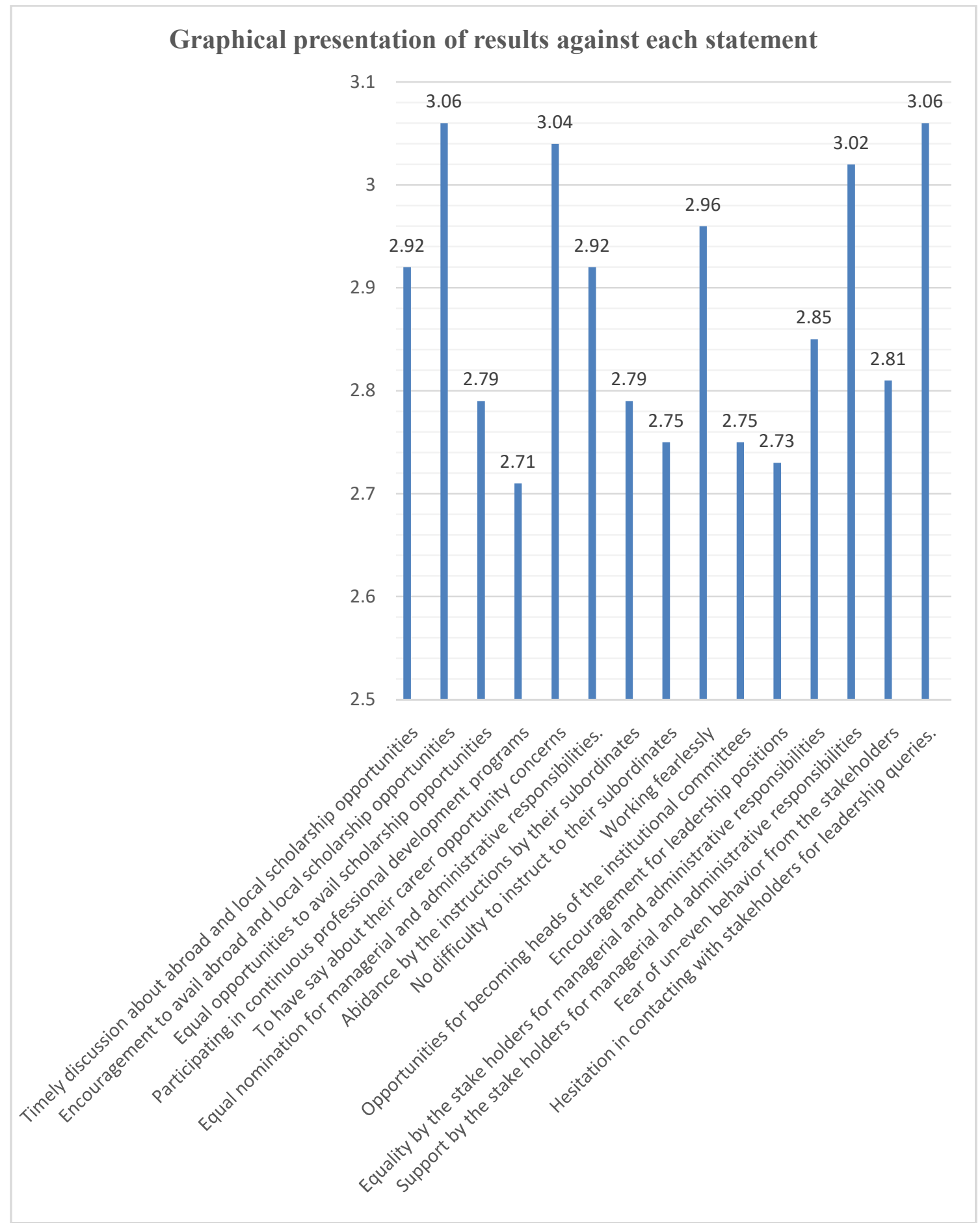


Analysis: The above table and graph shows that the timely discussion of the abroad and local scholarship opportunities were timely discussed with women leaders show slightly diverted towards disagreement as the mean score stood 2.92 and the standard deviation become .846. The results regarding encouragement to avail abroad and local scholarship opportunities show slightly diverted towards agreement where in the mean score is 3.06 and the standard deviation .836. The results regarding equal opportunities to be availed by the women leaders show diverted towards the disagreement where in the mean score stands 2.79 and the standard deviation .849. The results regarding participating in continuous professional development programs, the diversion is again towards the disagreement where in the mean score is 2.71 and the standard deviation is .771 . The results regarding to have say about their career opportunity concerns show slightly diverted towards agreement where in the mean score is 3.04 and the standard deviation .743. The results regarding equal nomination for managerial and administrative responsibilities, the diversion is again towards the disagreement where in the mean score is 2.92 and the standard deviation is .846 . The results regarding abidance by the instructions by their subordinates, the diversion is again towards the disagreement where in the mean score is 2.79 and the standard deviation is .798. The results regarding no difficulty to instruct to their subordinates, the diversion is again towards the disagreement where in the mean score is 2.75 and the standard deviation is .729. The results regarding working fearlessly, the inclination is again towards the disagreement where in the mean score is 2.96 and the standard deviation is .771. The results regarding opportunities for becoming heads of the institutional committees, the inclination is again towards the disagreement where in the mean score is 2.75 and the standard deviation is .812. The results regarding encouragement for leadership positions, the inclination is again towards the disagreement where in the mean score is 2.73 and the standard deviation is .707 . The results regarding equality by the stake holders for managerial and administrative responsibilities, the inclination is again towards the disagreement where in the mean score is 2.85 and the standard deviation is .899. The results regarding support by the stake holders for managerial and administrative responsibilities, the inclination is again towards the undecidedness where in the mean score is 3.02 and the standard deviation is .838. The results regarding fear of un-even behavior from the stakeholders, the inclination is again towards the disagreement where in the mean score is 2.81 and the standard deviation is .867 . The results regarding Hesitation in contacting with stakeholders for leadership queries, the inclination is slightly towards the agreement where in the mean score is 3.06 and the standard deviation is .810 . 
Table 6.2

Research questions and consolidated mean score results and analysis

\begin{tabular}{|l|c|c|}
\hline Theme 1 RQ1 & Mean & Std. Deviation \\
\hline Career related opportunities & 2.9042 & .34019 \\
\hline \multicolumn{3}{|c|}{ Theme 2 RQ2 } \\
\hline Managerial and administrative opportunities & 2.8333 & .31779 \\
\hline \multicolumn{3}{|c|}{ Theme 3 RQ3 } \\
\hline Support from High ups/ Stakeholders & 2.8958 & .37129 \\
\hline \multicolumn{3}{|c|}{ Consolidation } \\
\hline Consolidated results & 2.88 & .195 \\
\hline
\end{tabular}

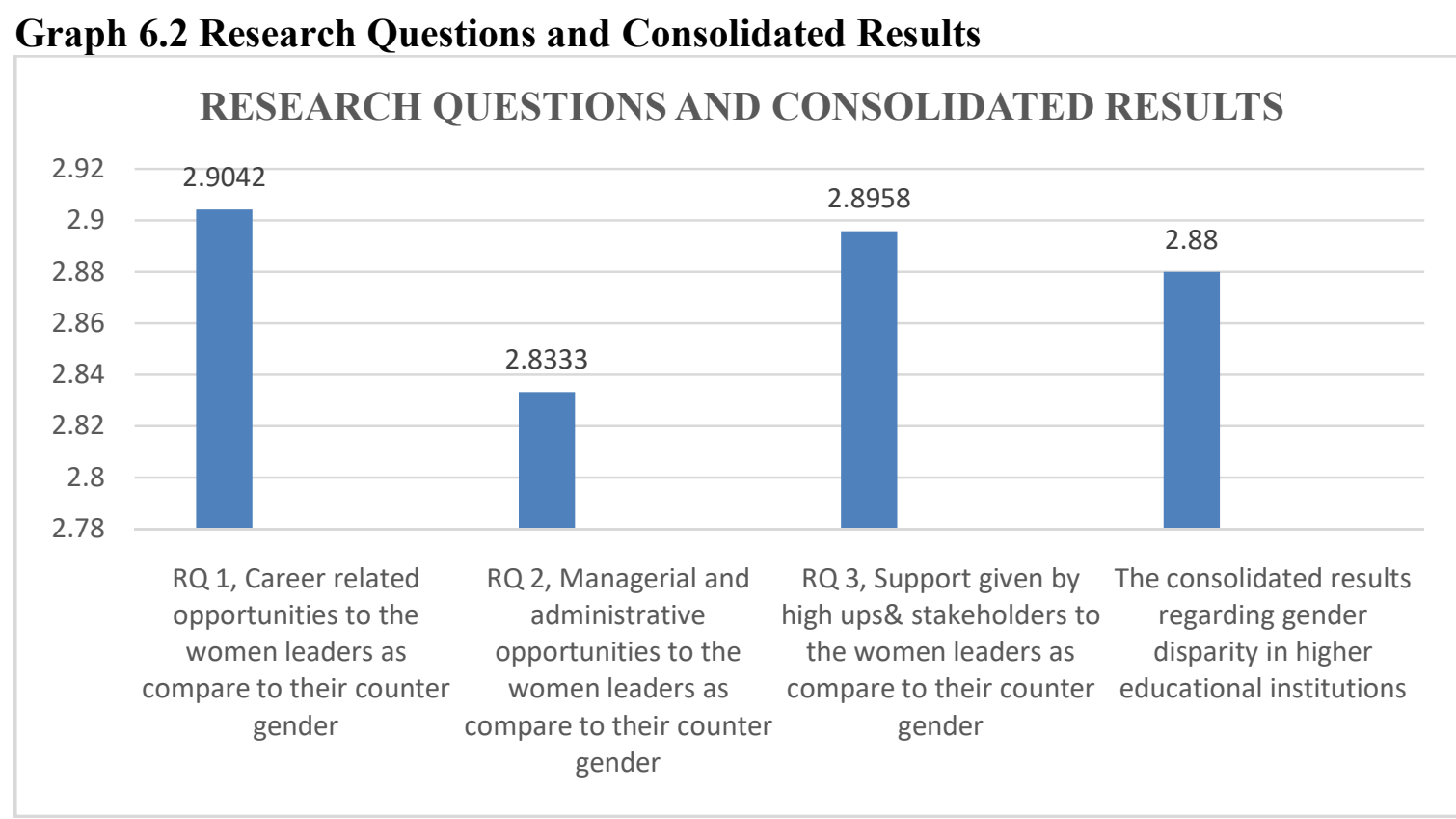

Analysis: The results of research question one which was regarding career related opportunities to the women leaders as compare to their counter gender covering sub areas such as, timely discussion of abroad and local scholarships, encouragement to avail those opportunities, participation in continuous professional development programs and have say about their career opportunity concerns, the above table and graph show that the respondents were inclined towards the disagreement where in the mean score is 2.9042 near to undecidedness and the standard deviation is .34019 , which depicts that the women leaders have lesser career related opportunities in their educational institutions. 
The results regarding the research question two which was regarding managerial and administrative opportunities to the women leaders as compare to their counter gender having sub areas such as equal nomination for managerial and administrative responsibilities, abidance by the instructions by their sub-ordinates, having no difficulty to instruct their sub-ordinates, having fearless working environment and opportunities for becoming heads of the institutional committees, the above table and graph show that the respondents were inclined towards the disagreement where in the mean score is 2.8333 and the standard deviation is .31779 .

The results regarding the research question three which was regarding support given by high ups\& stakeholders to the women leaders as compare to their counter gender having sub-themes such as encouragement for leadership positions, equality by the stake holders for managerial and administrative positions, support by the stake holders for managerial and administrative responsibilities, un-even behavior from the stakeholders and hesitation in contacting with stakeholders for leadership queries, showed undecidedness which revealed that the women leaders did not decide that whether the high ups\& stakeholders support the women leaders or not as compared to their counter gender. The results regarding Career related opportunities and managerial and administrative opportunities to the women leaders as compare to their counter gender, the results suggest disagreement that the women leaders avail equal carrier opportunities, where in the mean score is 2.8958 and the standard deviation is .37129 . These results resonate with assumptions and future concerns which were narrated by AAUW, (2016), where in it was dipcted that the statusco was a barrier without questioningneitherbeneficial norinevitable,

The consolidated results regarding gender disparity in higher educational institutions, according to the above table and graph reveal that the respondents were inclined towards the disagreement where in the mean score is 2.88 and the standard deviation is .195. The entirety of the results in consolidation showed inclined towards disagreement which revealed that gender disparity prevails in educational institution. These results also confirm the results of (Karadağ, 2018). The results of research report by Clerkin, (2017) do not resonate with curent research study. The research report of the Clerkin, (2017) showed 45:55 ratio of oppertunities for each feminine and musculine gender and showed workplace satisfaction of the surveyed respondents. The results of the current research study resonate with the assumption of AAUW, (2016), wherein, it was narrated that the gender parity was the most important for meeting the fairness at leadership levels, they further narrated that because of the male dominancy female are deprived of their chances at leadership levels and it was because, according to them the leaders avail greater status and honor which defers female leaders from such oppertunities, these results resonate with the reseach findings of (Shaukat, 2014). 


\section{Conclusions}

On the basis of the results of current research study, it is concluded that women leaders working in higher educational institutions have least career related opportunities, they are also put on distance to possess managerial and administrative positions and have least support from their high ups and stakeholders to work as a leader, as compared to their counter gender in higher educational institutions of District Shaheed Benazirabad.

\section{Recommendations}

This research study on the basis of its findings, recommended that the women leaders are equally beneficial for their institutions as was suggested by Thayer-Bacon, (2011) and AAUW, (2016) that the gender parity and equality was the most important for meeting the fairness at leadership levels. It is recommended that the women leaders might be given career and managerial and administrative related oppertuinities and support and encouragement from their high ups and stakeholders for carrying out their leadership responsibilities. The equalilty in gender related oppertuninties might work as a motivational factor for female literacy and their higher education as was found by (Malik, 2011; Clerkin, 2017).

\section{References}

AAUW. (2016). Barrier and Bias: The status of Women Leadership. American Association of University Women (AAUW), 1111 Sixteenth St. NW, Washington, $D C$ 20036,. Retrieved from: www.aauw.org

Asya, A.L. (2007). Feminizing Leadership in Arab Societies: The Perspectives of Omani Female Leaders . Women in Management Review, vol.1, pp.49-67.

Balc, A. B. (2017). Complexity Leadership: A Theoretical Perspective. International Journal of Educational Leadership and Management, vol.5:1, pp.30-59.

Baluch, M. A. (2009). Measuring Gender Disparity at Primary School Level in Pakistan. International NGO Journal, vol.4:5, pp.180-189.

Batool, S. Q., Sajid, M. A.\&Shaheen, I. (2013). Gender and Higher Education in Pakistan. International Journal of Gender and Women's Studies, vol.1:1, pp.15-28.

Batool, S. Q. \& Sajid, M. A. (2013). Barriers faced by women managers at universities. Middle East Journal of Scientific Research, vol.13:3, pp.22-34. 
Billot, J. G. (2007). How Principals Manage Ethnocultural Diversity: Learnings from Three Countries. International Studies in Educational Administration, vol.35:2, pp.3-19.

Blackmore, J. (2006). Deconstructing Diversity Discourses in the Field of Educational Management and Leadership. Educational Management Administration \& Leadership, vol.34,pp.181-199.

Blair, M. (2002). Effective School Leadership: The Multi-Ethnic Context. British Journal of Sociology, vol.2:1, pp.57-66.

Bolden, A. (2004). What is Leadership? Leadership South West Research Report 1. University of Exeter Center for leadership studies. Retrieved from: www.leadershipsouthwest.com

Bush, T. (2007). Educational Leadership and Management: Theory, Policy, and Practice . South African Journalof Education, vol.27:3, pp.391-406.

Catherine, C. E. \& Grossman, P. J. (2008). Men, Women, and Risk Aversion: Experimental Evidence. Handbook of Experimental Economics Results, 1, 10611073. Retrieved from: https://doi.org/10.1016/S1574-0722(07)00113-8

Chege, F. S. (2006). Girls' and Women's Education in Kenya Gender Perspectives and Trends. $\quad$ Retrieved from: www.library.unescoiicba.org/.../Girls\%20Education/.../Girls\%20and\%2

Cheng, B. C. (2004). Paternalistic Leadership and Subordinate Responses: Establishing a Leadership Model in Chinese Organizations. Asian Journal of Social Psychology, vol.7, pp.89-117.

Clerkin, C. (2017). What Women Want - And Why You Want Women - In the Workplace. Center for Creative Leadership.

Çobanoğlu, F. (2018). Gender Equality in Turkish Higher Education. International Journal of Higher Education, vol.7:5, pp.24-33. Retrieved from: http://ijhe.sciedupress.com

Cubillo, \&. B. (2003). Women into Educational Leadership and Management: International Differences? . Journal of Educational Administration, vol.41:3, pp.278-291. 
Devineau, S. C. (2018). Working in Higher Education in France Today: A Specific Challenge for Women. International Journal of Higher Education, vol.7:3, pp.66-79. Retrieved from: http://ijhe.sciedupress.com

Devineau, S., Couvry, C., Feliu, F. \& Renard, A. (2018). Working in Higher Education in France Today: A Specific Challenge for Women. doi:10.5430/ijhe.v7n3p209

DIRGHA, J. (2006). Education in Nepal: Meeting or Missing the Millennium Development goals? Contributions to Nepalese Studies, vol.33:2, pp.153-175.

Doob, C. (2015). Social Inequality and Social Stratification in US Society. Routledge.

Efeoğlu, E. U. (2017). Organizational Culture in Educational Institutions. International Journal of Social Science, vol.54, pp.39-56.

Funk, C. (2004). Female Leaders in Educational Administration: Sabotage Within Our Own Ranks. Advancing Women in Leadership Journal, vol.2:1, pp.1-14. Retrieved from: http://www.advancingwomen.com/awl/winter2004/Funk.html

Gail, M., Sullivan, Anthony, R. \& Artino, J. (2013). Analyzing and Interpreting Data from Likert-Type Scales. Journal of Graduate Medical Education, vol.5:4, pp.541-542.

Hird, M. J. (2004). Sex, Gender, and Science. New York: Palgrave Macmillan.

Huma, A. (2016). Study (9) Acess \& Equity . Retrieved from: http://hec.gov.pk/english/universities/projects/TESP/Documents/Final\%20Report $\% 2020160930 . p d f$

Imran, M. (2008). A Comparative Study of Quality of Education in Public and Private Secondary Schools of punjab.

Karadağ, T. N. (2018). Determining the Difficulties Female Managers Experience in Higher Education and the Factors Supporting. Educational Policy Analysis and Strategic Research, vol.13:3.

Khalid, R. (2011). Changes in Perception of Gender Roles: Returned Migrants. Pakistan Journal of Social and Clinical Psychology, vol.9, pp.16-20. 
Kostoulas, A. (2013). On Likert Scales, Ordinal Data and Mean Values. Retrieved from: https://achilleaskostoulas.com/2013/02/13/on-likert-scales-ordinal-data-andmean-values/

Lerner, J. S. \& Keltner, D. (2001). Fear, Anger and Risk. . Journal of Personality and Social Psychology, vol.81:1, pp.146-159. Retrieved from: http://dx.doi.org/10.1037/0022-3514.81.1.146

Lyness, K. S. \& Heilman, M. E. (2006). When Fit is Fundamental: Performance Evaluations and Promotions of Upper-Level Female and Male Managers. Journal of Applied Psychology, vol.91:4, pp.777-785. Retrieved from http://dx.doi.org/10.1037/0021-9010.91.4.777

Madhani, N. (2007). Career Development In Management at a Pakistani University: Is Gender a Factor, in Qureshi, R. \& J. F. A. Rarieya (Eds) Gender and Education in Pakistan. Karachi Oxford University Press: pp.216-236.

Mahmutovic, K. (2015). Would You Use Mean or Median as Measure of Central Tendency for Likert Scales (1-5)? Retrieved from: https://www.researchgate.net/post/Would_you_use_mean_or_median_as_measur e_of_central_tendency_for_likert_scales_1-5

Major, B., McFarlin, D. B. \& Gagnon, D. (1984). Overworked and Underpaid: On the Nature of Gender Differences in Personal Entitlement. Journal of Personality and Social Psychology, vol.47:6, pp.1399-1412.

Malik, S. (2011). A Portrayal of Women Educational Leadership in Pakistan. IManager's Journal on Educational Psychology, vol.5:2, pp.23-34.

Mehmood, T. (2011). Impact of Administrative Styles of Secondary School Heads on Teachers' Performance In NWFP,Faculty of Education Preston University, Kohat. Retrieved from: http//:prr.hec.edu.pk

Ministry of Planning and Development. (2015). Higher Education, in Action Plan - 201516. Retrieved on 2019, from: http://www.pc.gov.pk/wpcontent/uploads/2015/06/Ch24-HigherEducation.pdf

OECD. (2009). Creating Effective Teaching and Learning Environment: First Results from TALIS. PARIS CEDEX 16 , FRANCE: OECD Publication. 
Patel, G. \& Buiting, S. (2013). Gender Differences in Leadership Styles and the Impact Within Corporate Boards. The Commonwealth Secretariat, Social Transformation Programmes Division. Retrieved from: http://www.cpahq.org/cpahq/cpadocs/Genderdiffe.pdf

Poliner, S. J. \& Stefkovic, J. A. (2016). Ethical Leadership and Decision Making in Education: Applying Theoretical Perspectives to Complex Dilemmas. Routledge.

Morley, L. \& Crossouard, B. (2015). Women in Higher Education Leadership in South Asia: Rejection, Refusal, Reluctance, Revisioning: Project Report. British Council. University of Sussex, Center for Higher education \& Equity Research.

Rarieya, J. F. (2017). Women in Educational Leadership: A Comparison of Kenyan and Pakistani Women Educational Leaders. Quality in Education. Retrieved from: http://ecommons.aku.edu/book_chapters/85

Rostron, M. (2009). Liberal Arts Education in Qatar: Intercultural Perspectives. Intercultural Education, vol.20:3, pp.219-229. Retrieved from: https://doi.org/10.1080/14675980903138517

Sales, V. (1999). Women Teachers and Professional Development: Gender Issues in the Training Programs of the Aga Khan Education Service, Northern Areas, Pakistan. International Journal of Educational Development, vol.19:4, pp.9-22.

Sen, G. \& Mukherjee, A. (2014). No Empowerment without Rights, No Rights without Politics: Gender-equality, MDGs and the post-2015 Development Agenda,Journal of Human Development and Capabilities, vol.15:2-3, pp.188202. Retrieved from: https://doi.org/10.1080/19452829.2014.884057

Shaukat, S. S. (2014). Gender Discrimination in Higher Education in Pakistan: A Survey of University Faculty. Eurasian Journal of Educational Research, vol.56, pp.109126. Retrieved from: http://dx.doi.org/10.14689/ejer.2014.56.2

Smulders, A. E. (1998). Creating Space for Women: Gender Linked Factors in Managing Staff in Higher Education Institutions. UNESCO, International Institute of Educational Planning.

Stephen, M. Q., Wade, A. B., Fuligni, A., Graham, S., Oritz, S. \& Worrell, F. C. (2012). Ethnic and Racial Disparities in Education: Psychology's Contributions to Understanding and Reducing Disparities; APA Presidential Task Force on Educational Disparities. Retrieved from: http://www.apa.org/ed/resources/racialdisparities.aspx 
Suleman, Q. G. (2015). Challenges to Successful Total Quality Management Implementation in Public Secondary Schools: A Case Study of Kohat District, Pakistan. Journal of Education and Practice, vol.6:15, pp.123-134.

Thayer-Bacon. (2011). Befriending (white) Women Faculty in Higher Education? . Advancing Women in Leadership, vol.31, pp.23-33.

UNESCO. (2002). Women and Management in Higher Education: A Good Practice Handbook Follow-up to the World Conference on Higher Education.

Williams. (2004 ). Hitting the Maternal Wall. Academe, vol.90:6, pp.16-20.

Dr. Tayyaba Zarif is Professor in the Department of Education and Vice Chancellor Shaheed Benazir Bhutto University, Shaheed Benazirabad.

Dr. Safia Urooj is Incharge\& Assistant Professor in the Department of Teacher Education, University of Karachi.

Abdul Nabi Gorchani is Lecturer in the Department of Education, Shaheed Benazir Bhutto University, Shaheed Benazirabad. 